BIOMEDICAL AND BIOSOCIAL ANTHROPOLOGY
$\begin{gathered}\text { Official Journal of the International Academy } \\ \text { of Integrative Anthropology } \\ \text { journal homepage: http://bba-journal.com }\end{gathered}$

\title{
Features of the dental status of the Nogais who lived on the territory of Ukraine in the 15th century
}

Kaskova L. F.', Yanko N. V.1, Kulai O. O.', Chupryna L. F.', Artemyev A. V.:

${ }^{1}$ Ukrainian Medical Stomatological Academy, Poltava, Ukraine

2Public institution "Center for the Protection and Research of Archaeological Monuments" Poltava Regional Council, Poltava, Ukraine

\section{ARTICLE INFO}

Received: 06 August, 2020

Accepted: 04 September, 2020

UDC: $616.31-07(477=512.123) " 14 "$

\section{CORRESPONDING AUTHOR}

e-mail: latned@ukr.net

Yanko N. V.
The condition of teeth in ancient populations living on the territory of Ukraine has been little studied. The aim of the work is to study the dental status of the 15th century Nogais, and to carry out a comparative analysis of the data obtained with the state of the dento-jaw system of medieval populations that lived on the territory of modern Ukraine in the 9 th - early 15 th centuries. The object of the study was 48 Nogai skeletons (main group) and 118 representatives of medieval cultures (control group). The research method was a method for analyzing the skeletal tissue of ancient people, developed by the authors. The prevalence and intensity of caries, the prevalence of dento-jaw anomalies, dental calculus and periodontal diseases were studied. Statistical analysis was performed using the Pearson $X^{2}$ test. It was found that the prevalence of dental caries in the main group is lower than in the control group $18.75 \%$ and $37.28 \%$ respectively, $p<0.05)$. It was also found that this indicator significantly differed in men of both groups $(p<0.05)$, while in women it did not differ $(p>0.1)$. It was found that in the main group, compared with the control group, the frequency of primary adentia was higher (16.67\% and $6.68 \%$ respectively, $p<0.05)$, but the prevalence of anomalies in the position of individual teeth and occlusion was lower $(4.17 \%$ and $21.18 \%$ respectively, $p<0.05$,). It was found that the prevalence of dental calculus in the main group is two times higher than in the control group ( $89.50 \%$ and $41.0 \%$ respectively, $p<0.0001)$. Also, $15.0 \%$ of Nogai men showed a decrease in the height of the alveolar process of the jaws, which is characteristic of periodontitis; in women, such changes were not found due to the low average age of survival. Thus, the 15th century Nogai population had a lower prevalence of caries and dento-maxillary anomalies than the medieval populations that lived on the territory of modern Ukraine in the 9th - early 15th centuries. Keywords: Nogais of the 15th century, representatives of medieval cultures, prevalence of caries, dental-maxillary anomalies, dental calculus, periodontal disease.

\section{Introduction}

More than 20 years have passed since the beginning of our analysis of the bone remains of medieval residents who lived on the territory of modern Ukraine. The emergence of recent studies on the anthropology of the teeth of ancient people living in different regions of the world [4-6, 15, 21] contributes to an increase in the level of such analysis in general. Unfortunately, the condition of teeth in ancient populations living on the territory of Ukraine remains poorly understood, as evidenced by a few works $[1,8,13]$. The territory of modern Ukraine has been a migration zone for ancient nomadic peoples for thousands of years. The attention of the authors was attracted by the Nogais, who appeared in the lower Dnipro region in the 15th century [17], whose dental status had not been previously studied. Therefore, we continue a series of our studies devoted to the dental morbidity of populations that lived at different historical times on the territory of modern Ukraine [9, 10, 12, 23].

The aim of the work is to study the dental status of the 15th century Nogai, and to carry out a comparative analysis of the data obtained with the state of the dento-jaw system of medieval populations that lived on the territory of modern Ukraine in the 9th - early 15 th centuries.

\section{Materials and methods}

The material for the study was 48 skeletons (20 - women, 28 - men) of 15th century Nogais from the territory of the modern Zaporizhzhya region (main group) of varying degrees of preservation [14], obtained as a result of excavations of 
the archaeological expedition of Zaporizhzhya National University in 2016-2019 and saved in its storerooms. MamaiGora is the largest burial ground in the Northern Black Sea region, located near the village Velyka Znamenka of the Kamensko-Dniprovskiy district of the Zaporizhzhya region on the left bank of the modern Kakhovskiy reservoir. In connection with the crumbling coastline, since 1988, the expedition of the Zaporizhzhya National University has been conducting security research here [16]. Since 2006, complexes of the Nogai time have been studied in the western section [17], and at the end of 2019, 185 burials were excavated.

The study was carried out by the method of analyzing the skeletal tissue of ancient people [11], developed by the authors of this publication on the basis of the Laboratory of Historical and Medical Anthropology of the Communal Institution "Center for the Protection and Research of Archaeological Monuments" of the Poltava Regional Council and the Department of Pediatric Therapeutic Dentistry with the Prevention of Dental Diseases of the Ukrainian Medical Dental Academy. The main indicators of physical development (muscle relief and changes in joints, including those of a professional nature or those related to age) were investigated. Sex and age were determined according to the schemes generally accepted in forensic medicine and physical anthropology [2], the height of individuals - according to $M$. Trotter's formulas [18]. Described, first of all, the skeletons of women, then men, noted changes in the skeleton. Individuals are classified by age groups according to the periods of development of the dento-jaw system: from 12 to 21 years (permanent bite at the stage of formation), from 21 to 40 years (permanent bite during its functional heyday) and from 40 to 60 years (aging period of permanent bite).

The pathology of the teeth and jaws was fully described (almost a complete set of teeth was preserved for analysis), as well as calculus. The teeth are numbered in accordance with the classification proposed by the World Health Organization [22]. The prevalence of caries was determined by the frequency of occurrence of carious and lost teeth due to caries in individuals, the intensity of caries was determined by the sum of carious and lost teeth due to caries.

For a comparative analysis, previously studied bone remains of medieval residents of the Poltava, Kyiv, Chernigiv, Khmelnytsky, Sumy, Kharkiv, Kirovograd and Zaporizhzhia regions (control group), which represented the old Russian culture (IX-XIII centuries) and the period of the Golden Horde (XIII - early XV century). There are 39 female skeletons, 79 male skeletons (118 in total) [12].

The Pearson $x^{2}$ test was used to explain the significant differences between the group indicators. The results were classified as statistically significant at $p<0.05$.

\section{Results}

In the main group, women during the formation of a permanent bite are represented by 10 individuals; in the period of the formed permanent bite - 3; during the aging period of permanent occlusion - 7. The average height of the female contingent is $159.0 \mathrm{~cm}$. The average age is 20.5 years.

Men in the period of permanent bite formation are represented by 3 individuals; in the period of the formed permanent bite - 13; during the aging period of permanent occlusion - 12. The average height of the male contingent is $165.5 \mathrm{~cm}$. The average age is 40.0 years.

The prevalence of dental caries in women of the main group was $30.0 \%$, the intensity of caries was 0.57 teeth. Caries in women is presented during the formation of a permanent bite in one woman with the loss of 16 and 27 teeth and destroyed by $1 / 226$ tooth (Fig. 1 ); during the period of stabilization of the permanent occlusion in one woman deep caries of 27 and 28 teeth. During the aging period of permanent occlusion, caries was detected in three women: in the first, the lifetime loss of 47 and 48 teeth (Fig. 2); in the second, the loss of $18,17,28,38,41$ and 48 teeth; in the third - teeth 26, 27 and 28 are affected.

In women, three types of tartar were found in $95.0 \%$ of cases: 1) "thin line" - 10;2) "overhanging lump" - 8; 3) mixed form - 1 .

Dental-jaw anomalies in Nogai women are presented: 1) primary adentia of wisdom teeth - 3 cases, lateral lower incisors - 1 case; 2) diastema up to $5 \mathrm{~mm}$ - 1 case.

Also, a woman of 60-65 years old had a lifetime loss of twenty-three teeth, the nature of which was not possible to establish, since the remaining teeth were not carious and there was no loss of the height of the alveolar process on

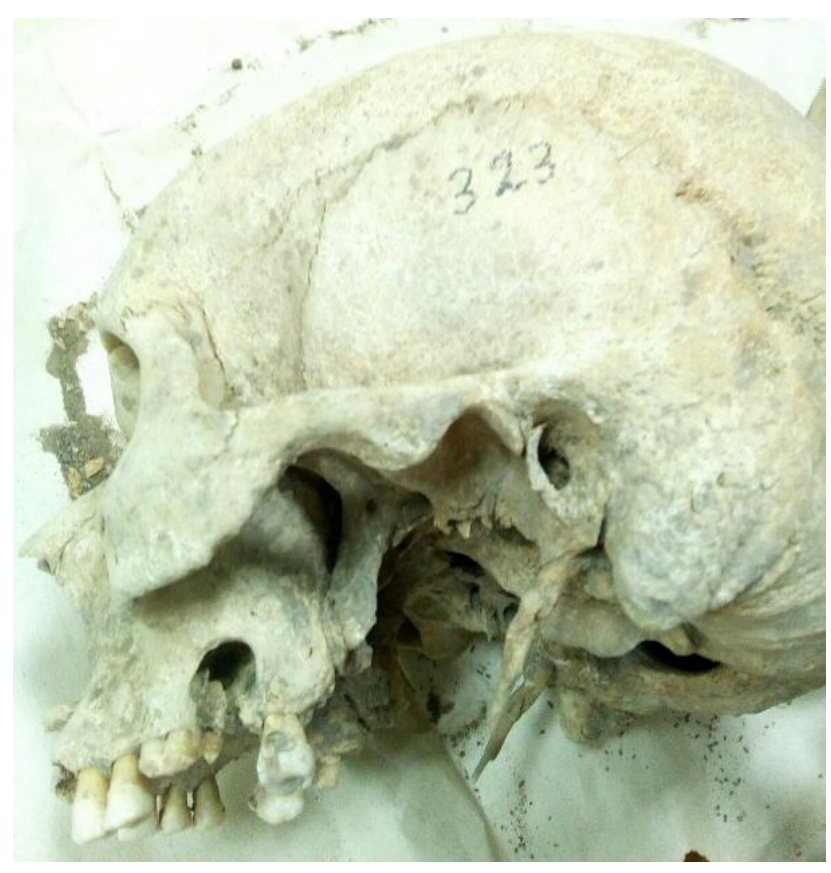

Fig. 1. Burial No. 323 (excavations in 2017), the skull of a young woman $16-18$ years old, body length $-148.0-150.0 \mathrm{~cm}$. During her lifetime, the 27 th tooth was lost due to complications of caries. The dental bed has not healed at the time of death. 26 tooth is destroyed by complications of caries on $1 / 2$ crown. 


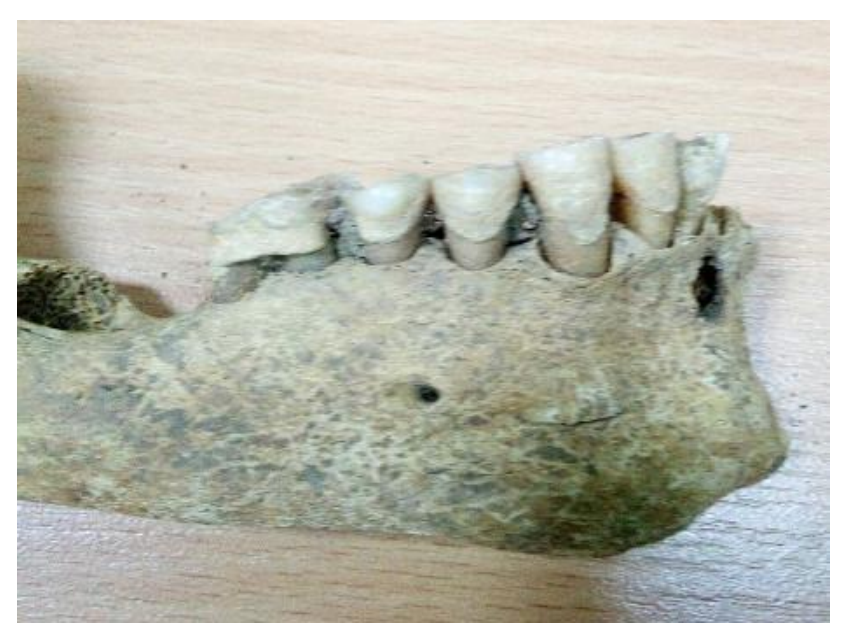

Fig. 2. Burial No. 309 (excavations in 2016), the lower jaw of a woman of 50-55 years old, with a body length of $150.0-152.0 \mathrm{~cm}$. Intravital loss of 47 and 48 teeth, the holes of which are overgrown. Tartar in the form of an "overhanging lump" on all preserved teeth.

both jaws. One woman evidently had a benign formation of the lower jaw in the region of the anterior group of teeth on the left. Teeth injuries, as well as changes in the jaw bones, characteristic of periodontal diseases, were not revealed in women.

The prevalence of caries in the male group was $14.0 \%$, the intensity of caries was 0.32 teeth. In men, in many cases, it is not possible to determine the cause of the loss of teeth, since both trauma and periodontal disease could be factors. Caries is precisely established only in men who died during the aging of permanent occlusion: 1) an individual 45-50 years old - caries of the 37th tooth in the cervical region; 2) an individual $50-60$ years old - a cavity in the 37th tooth, and $38,36,46,47$ and 48 teeth are lost due to complications of caries; 3) an individual 60-65 years old, complicated caries of the 26th tooth with destruction up to $1 / 2$ of the crown; 4) an individual 70-75 years old, complicated caries of the 26th tooth with destruction up to $1 / 2$ of the crown.

In men, 3 cases of periodontal tissue diseases were revealed (15.0\%): 1) an individual of 50-55 years old with a decrease in the height of the alveolar process and without loss of teeth; 2) an individual 50-60 years old with the loss of $18,24,28,38,37,47$ and 48 teeth, as well as a decrease in the height of the alveolar process along the entire length of the dental arches; 3) an individual 60-65 years old with the loss of fourteen teeth on both jaws with a decrease in the height of the alveolar process.

In men, two cases of dental injuries were identified: complete dislocation of $38,37,36$ and 35 teeth in an individual of 35-40 years old and complete dislocation of 47 and 48 teeth in an individual of 50-60 years old.

Also, a 50-60-year-old man was found to have an archer's "symptom complex" based on specific patterns on his teeth, indicating that he was biting a string of bow.

In Nogai men, two types of tartar were found in $85.71 \%$ of cases: 1) "fine line" - 13; 2) "overhanging lump" - 11; no other forms of dental calculus were found.

Dental anomalies: 1) primary adentia of wisdom teeth 4 cases; 2) crowding of teeth in the frontal area of the upper and lower jaw (individual 20-25 years old) - 1 case. One individual (65-70 years old) was diagnosed with age-related wear of the teeth, reaching a full section of the crowns, provided that the teeth of a permanent bite are completely preserved.

The data of a comparative analysis of caries indicators in the 15th century Nogais and the population of Ukraine in the 9th - early 15th centuries are presented in Table 1.

In general, the prevalence of caries in the control group was higher than in the main group $\left(x^{2}=4.18, d f=1, p<0.05\right)$. This indicator was significantly different in men of both periods $\left(x^{2}=4.37, d f=1, p<0.05\right)$, while in women it was the same ( $p>0.1)$. There was no difference in the prevalence of caries in the sexual aspect both in the main $\left(x^{2}=1.71, d f=1, p>0.1\right)$ and in the control group $\left(x^{2}=2.14, d f=1, p>0.1\right)$. The intensity of caries in the main group was lower than in the control group due to the same tendency in men, but it was not possible to determine the significance of the differences due to the lack of necessary data for the control group $[9,10,12]$.

Table 1. The prevalence and intensity of caries among the population of Ukraine in the studied epochs (\%).

\begin{tabular}{|c|c|c|c|c|c|c|c|c|c|}
\hline \multirow{2}{*}{ Archaeological culture } & \multicolumn{3}{|c|}{ Women } & \multicolumn{3}{c|}{ Men } & \multicolumn{3}{c|}{ Total } \\
\cline { 2 - 11 } & $\mathrm{n}$ & $\mathrm{PC}$ & $\mathrm{Cl}$ & $\mathrm{n}$ & $\mathrm{PC}$ & $\mathrm{Cl}$ & $\mathrm{n}$ & $\mathrm{PC}$ & $\mathrm{Cl}$ \\
\hline 15th century Nogais & 28 & 17.85 & 0.57 & 20 & 20.0 & 0.45 & 48 & 18.75 & 0.52 \\
\hline $\begin{array}{c}\text { Old Russian culture and the period of } \\
\text { the Golden Horde }\end{array}$ & 39 & 30.77 & 0.50 & 79 & 35.44 & 2.10 & 118 & 37.28 & 1.60 \\
\hline
\end{tabular}

Notes: PC - prevalence of caries; $\mathrm{Cl}$ - caries intensity; $\mathrm{n}$ - number of skeletons.

Table 2. The prevalence of dental-jaw anomalies among the population of Ukraine in the studied epochs (\%).

\begin{tabular}{|c|c|c|c|c|c|c|c|c|c|}
\hline \multirow{2}{*}{ Archaeological culture } & \multicolumn{3}{|c|}{ Women } & \multicolumn{3}{c|}{ Men } & \multicolumn{3}{c|}{ Total } \\
\cline { 2 - 11 } & $\mathrm{n}$ & PA & APITB & $\mathrm{n}$ & PA & APITB & $\mathrm{n}$ & PA & APITB \\
\hline 15th century Nogais & 28 & 14.28 & 3.57 & 20 & 20.0 & 5.0 & 48 & 16.67 & 4.17 \\
\hline $\begin{array}{c}\text { Old Russian culture and the period of } \\
\text { the Golden Horde }\end{array}$ & 39 & 7.69 & 12.82 & 79 & 6.32 & 25.31 & 118 & 6.78 & 21.18 \\
\hline
\end{tabular}

Notes: PA - primary adentia; APITB - anomalies in the position of individual teeth and bite; $n$ - number of skeletons. 
The data of a comparative analysis of dento-maxillary anomalies in the 15th century Nogais and the population of Ukraine in the 9th - early 15th centuries are presented in Table 2. Primary adentia in the main group was found significantly more often than in the control group $\left(x^{2}=3.91\right.$, $\mathrm{df}=1, \mathrm{p}<0.05)$, and anomalies in the position of individual teeth and occlusion are less common $\left(x^{2}=7.20, d f=1\right.$, $p<0.01)$. There were no sex differences between Nogai men and women in terms of dento-maxillary anomalies $(p>0.5)$. The prevalence of anomalies in the position of individual teeth and occlusion was significantly higher in the control group $\left(\mathrm{x}^{2}=4.28, \mathrm{df}=1, \mathrm{p}<0.05\right)$. Primary adentia was more common in men of the main group than in the control group with a probability close to significant $(p=0.05)$, while in women it did not differ $(p>0.1)$.

In the control group, injuries were represented by traumatic fractures of the crowns of teeth in 3 women and 4 men [10], in the main group there were complete dislocations of teeth in 2 men. Noteworthy is the fact that in the control group tartar was found in $41.0 \%$ of cases [9], that is, 2 times less often compared with the main group $(89.5 \%)\left(x^{2}=43.1, d f=1\right.$, $\mathrm{p}<0.001)$.

\section{Discussion}

The short age of survival in women that we have established is due to the fact that more than $50.0 \%$ of them did not live to be 20 years old. The average age of survival in the main male group is associated with a significant number of people over 20 years old. It was higher than that of medieval European groups [20], however, most likely it depended on a random selection of skeletons, and the final conclusion about it can only be made after analyzing the skeletons of the population of the entire burial ground.

The prevalence and intensity of caries among the Nogais who lived on the territory of Ukraine in the 15th century was lower than among individuals who lived on the territory of Ukraine in the 9th - early 15th centuries. This difference can be explained by the difference in diet, when the sedentary Slavic population consumed mainly plant foods, and the Nogais, who moved to the Lower Dnieper region at the end of the 15th century from the Crimea [17] - the meat and dairy food of nomads.

Sex differences within the studied populations were not revealed, although it should be noted that the low prevalence of caries in Nogai was achieved due to the low rate in men. It is likely that it was men who were more nomadic and consumed fewer carbohydrates, which contributed to a decrease in dental caries.

Anomalies in the bite and individual teeth are the result of the influence of genetic factors, somatic diseases that affect the development of teeth and environmental factors, including trauma, dental caries and food habits. Primary adentia of third molars is a congenital abnormality and is

\section{References}

[1] Arnold, W. H., Naumova, E. A., Koloda, V. V., \& Gaengler, P. (2007). Tooth wear in two ancient populations of the Khazar most common in comparison with adentia of other teeth; the second place in the frequency of adentia belongs to the upper lateral incisors [19], which was also observed in our study. The significant difference in primary adentia that we established between the Nogais and individuals of earlier cultures proves that they represented genetically different populations. The fact that the population belonging to the Old Russian culture and archaeological culture of the Golden Horde period had a higher prevalence of anomalies in the position of individual teeth and bite than the Nogais $(p<0.05)$ can be explained by both genetic factors and the influence of the nature of the diet and a higher incidence of caries teeth. The same trend was observed in Nogai men with a low prevalence of tooth caries and a nomadic lifestyle with a meat and milk diet.

Tartar is the leading factor for the development of periodontal diseases, however, the changes that are found on the skeletal remains indicate a severe degree of their manifestation - periodontitis, which occurs with resorption of the alveolar bone. As in modern people, the frequency of periodontal disease in ancient people depended on the prevalence of dental calculus [7, 20]. In the Nogai population, the average survival age for women was 20.5 years, and for men, 40.0 years. It is generally known that the incidence of periodontal disease increases with age. Therefore, with the prevalence of tartar in $89.5 \%$ of men, which did not differ from that in women $(95.0 \%), 15.0 \%$ of Nogai men had bone changes in the alveolar process of the jaw. It should be noted that tartar could have been removed during excavations of the examined skeletons of the control group, where its frequency was below $41.0 \%$. At the same time, the level of accumulation of soft plaque on the teeth in the control group was obviously higher, which led to a higher incidence of caries compared to the main group.

The use of the obtained data is promising for the creation of an atlas of dental diseases of ancient populations living on the territory of Ukraine.

\section{Conclusions}

1. The prevalence of caries in the Nogai population of the 15th century is lower than in the medieval populations of the 9th - early 15th centuries living on the territory of modern Ukraine. The decrease in the indicator is probably caused by the nomadic way of life of Nogai men.

2. The prevalence of anomalies in the position of individual teeth and bite in the Nogai population is also lower than in the compared medieval populations, which can be explained by both genetic factors and the influence of a plant diet and a lower incidence of dental caries.

3. Against the background of the high prevalence of dental calculus, periodontal diseases in Nogai were revealed only in men, which is explained by the lower average age of survival in women.

Kaganat region in the Ukraine. International Journal of Osteoarchaeology, 17(1), 52-62. doi: 10.1002/oa.859 
[2] Buikstra, J. E. (1994). Standards for data collection from human skeletal remains. Arkansas archaeological survey research series, 44

[3] Cummins, N. (2014). Longevity and the Rise of the West: Lifespans of the European Elite, 800-1800. Available at SSRN 2496939. doi: 10.2139/ssrn.2496939

[4] D'Ortenzio, L., Ribot, I., Kahlon, B., Bertrand, B., Bocaege, E., Raguin, E., ... \& Brickley, M. (2018). The rachitic tooth: The use of radiographs as a screening technique. International journal of paleopathology, 23, 32-42. doi: 10.1016/j.jpp.2017.10.001

[5] Gritskevich, D. S. (2019). Палеопатологические проявления на остеологическом материале у сельского населения XIV-XVI вв. (на примере могильника Ивесь) [Paleopathological manifestations at osteological material in the village population from the XIV-XVI cc. (for sample in cemetery lves)]. Актуальные вопросы антропологии Topical issues of anthropology, (14), 67-80.

[6] Järve, M., Saag, L., Scheib, C. L., Pathak, A. K., Montinaro, F., Pagani, L., ... \& Kushniarevich, A. (2019). Shifts in the Genetic Landscape of the Western Eurasian Steppe Associated with the Beginning and End of the Scythian Dominance. Current Biology, 29(14), 2430-2441. doi: 10.1016/j.cub.2019.06.019

[7] Karkus, J. (2018). Periodontitis in 14th-17th century inhabitants of Brzesc Kujawski in north-central Poland. AnthropologicAl review, 81(4), 423-434. doi: 10.2478/anre-2018-0037

[8] Karsten, J. K., Heins, S. E., Madden, G. D., \& Sokhatskyi, M. P. (2015). Dental health and the transition to agriculture in prehistoric Ukraine: a study of dental caries. European Journal of Archaeology, 18(4), 562-579. doi: 10.1179/ 1461957115Y.0000000004

[9] Kas' kova, L. F., Artem'ev, A. V., Berezhnaia, E. E., \& Amosova, L. I. (2014). Features' dental status population of the territory of Ukraine in different historical epochs. Georgian medical news, (237), 35-40. PMID: 25617098

[10] Kas`kova, L. F., \& Artem `ev, A. V. (2012). Состояние зубочелюстной системы населения Украины эпохи меди-средневековья [State of dental-maxillary system in population of Ukraine in the Copper-Medieval Ages]. Український стоматологічний альманах - Ukrainian dental almanac, 1(2), 130133.

[11] Kaskova, L. F., Kulatova, I. M., Koverko, O. V., Chupryna, L. F., Artemyev A. V., \& Andriyanova, O. Yu. (2020). Рекомендації до збору та збереження одонто-антропологического материалу з метою подальшого медичного дослідження [Recommendations for collection and storage of dental anthropological material for following medical study]. Свidouтво про реєстрацію авторського права на твір Certificate of authorship. № 95913, Ukraine.

[12] Kaskova, L. F., Makovka, I. L., Morgun, N. A., Zaytsev, A. V., \& Artemyev A. V. (2016). Стоматологическая заболевае- мость в эпоху позднего средневековья [Stomatological morbidity in late middle ages]. Український стоматологічний альманах - Ukrainian dental almanac, 1(1), 90-94.

[13] Lillie, M. C. (1996). Mesolithic and Neolithic populations of Ukraine: indications of diet from dental pathology. Current Anthropology, 37(1), 135-142. doi: 10.1086/204479

[14] Mamonova, N. N, Romanova, G. P, \& Haritonov, V. M. (1989). Первичная обработка и определение антропологического материала в полевых условиях [Primary processing and examination of anthropological material in filed studies]. Методика полевых археологических исследований Method of field archaeological studies, Л, 50-83.

[15] Tomczyk, J., Regulski, P., Lisowska-Gaczorek, A., \& Szostek, K. (2020). Dental caries and stable isotopes analyses in the reconstruction of diet in Mesolithic (6815-5900 BC) individuals from Northeastern Poland. Journal of Archaeological Science: Reports, 29, 102141. doi: 10.1016/j.jasrep.2019.102141

[16] Toščev, G. N. (2005). Die neolithische Nekropole Mamaj-Gora im unteren Dneprgebiet. Godišnjak, 34, 21-45.

[17] Toschev, A. G. (2014). К проблеме заселения Нижнего Поднепровья ногайскими племенами в XV в. [About problem of settlement of the left bank of the Dnieper by Nogai in the XV c.]. Probleme actuale ale arheologiei, etnologiei si studiului artelor (editia a VI-a): Rezunatele comunicărilor de conferin?? stiintifică cu participare internatională, Mai 22-23, 2014 (pp. 46-47). Chisinău.

[18] Trotter, M. (1970). Estimation of stature from intact long limb bones. Personal identification in mass disasters, 71-83.

[19] Vodanović, M., Galić, I., Strujić, M., Peroš, K., Šlaus, M., \& Brkić, H. (2012). Orthodontic anomalies and malocclusions in Late Antique and Early Mediaeval period in Croatia. Archives of oral biology, 57(4), 401-412. doi: 10.1016/ j.archoralbio.2011.09.006

[20] Vodanović, M., Peroš, K., Zukanović, A., Knežević, M., Novak, M., Šlaus, M., \& Brkić, H. (2012). Periodontal diseases at the transition from the late antique to the early mediaeval period in Croatia. Archives of oral biology, 57(10), 1362-1376. doi: 10.1016/j.archoralbio.2012

[21] Willmann, C., Mata, X., Hanghoej, K., Tonasso, L., Tisseyre, L., Jeziorski, C., ... \& Esclassan, R. (2018). Oral health status in historic population: Macroscopic and metagenomic evidence. PloSone, 13(5), e0196482. doi: 10.1371/ journal.pone.0196482

[22] World Health Organization. (2013). Oral health surveys: basic methods. World Health Organization. https://www.who.int/ oral_health/publications/9789241548649/en/

[23] Yanko, N. V., Artemyev, A. V., \& Kaskova, L. F. (2017). Frequency of dental caries in children in the Early Iron Age and the Medieval populations from Ukraine. Anthropological Review, 80(4), 415-426. doi: 10.1515/anre-2017-0030 